\title{
MEDICAL STUDENTS' AWARENESS OF ORTHODONTICS- A COMPARATIVE QUESTIONNAIRE SURVEY STUDY BETWEEN THE STUDENTS OF A MEDICAL COLLEGE ATTACHED WITH A DENTAL COLLEGE AND A STAND-ALONE MEDICAL COLLEGE
}

\author{
McQueen Mendonca ${ }^{1}$, Audrey Madonna D'cruz², Crystal Runa Soans ${ }^{3}$, Murli Patla ${ }^{4}$, Azhar Mohammed ${ }^{5}$, Prajwal Shetty K6, \\ Kaushik Shetty ${ }^{7}$ Akhil Shetty ${ }^{8}$
}

${ }_{1}^{1}$ Reader, Department of Orthodontics, A. B. Shetty Dental College, Mangalore, Karnataka, India. 2 Professor, Department of Community Dentistry, A. B. Shetty Dental College, Mangalore, Karnataka, India.

${ }^{3}$ Lecturer, Department of Orthodontics, A. B. Shetty Dental College, Mangalore, Karnataka, India.

${ }^{4}$ Lecturer, Department of Orthodontics, A. B. Shetty Dental College, Mangalore, Karnataka, India.

${ }_{5}^{5}$ ecturer, Department of Orthodontics, A. B. Shetty Dental College, Mangalore, Karnataka, India.

${ }^{6}$ Reader, Department of Orthodontics, A. B. Shetty Dental College, Mangalore, Karnataka, India.

${ }^{7}$ Lecturer, Department of Orthodontics, A. B. Shetty Dental College, Mangalore, Karnataka, India.

${ }^{8}$ Professor, Department of Orthodontics, A. B. Shetty Dental College, Mangalore, Karnataka, India.

\section{BACKGROUND}

\section{ABSTRACT}

The early treatment of malocclusion is important, because it affects quality of life. Medical practitioners have an important role to play for patients with a vast majority of health-related complaints, as they are the primary caregivers. Involvement of medical practitioners in the process of screening, detection and referral of patients with oral health problems including malocclusion will be beneficial for the prevention and management of oral diseases and effective delivery of oral health care. There have been no known studies which have compared the responses of a medical college attached with a dental college with a stand-alone medical college.

Hence, it was considered pertinent to conduct this study to assess as to whether there would be any differences in attitudes and awareness of orthodontics between medical students with an attached dental college and students in a stand-alone medical college.

\section{MATERIALS AND METHODS}

This comparative cross-sectional study was conducted in Mangalore among 132 first year MBBS students at a medical college with a dental college $\{A\}$ and 127 first year MBBS students in a stand-alone medical college $\{B\}$. A pre-piloted, validated, selfadministered questionnaire was distributed among the students. Data collected was entered in Microsoft Excel. The statistical software package SPSS version 16.0 for Windows was employed for data analysis. Pearson's Chi-square test was used and a p-value less than 0.05 were considered statistically significant.

\section{RESULTS}

There was a difference between male and female students' awareness and their attitudes towards orthodontics. There were significant differences in the attitudes and awareness of the subject of Orthodontics between those students studying in a medical college with an attached dental college when compared with those medical students studying in a stand-alone medical college.

\section{CONCLUSION}

The medical students who studied in an institution with an attached dental college had better awareness of the subject of orthodontics as compared to medical students of a stand-alone medical college. The medical students with and without a dental college had average awareness of orthodontics as a sub-specialty of dentistry. A basic introduction to dental sub-specialties would help them identify dentofacial problems and make appropriate referrals.

\section{KEY WORDS}

Students, Awareness, Orthodontics.

HOW TO CITE THIS ARTICLE: Mendonca M, D'cruz AM, Soans CR, et al. Medical students' awareness of orthodontics- a comparative questionnaire survey study between the students of a medical college attached with a dental college and a stand-alone medical college. J. Evolution Med. Dent. Sci. 2018;7(32):3569-3576, DOI: 10.14260/jemds/2018/802

'Financial or Other Competing Interest': None.

Submission 19-06-2018, Peer Review 19-07-2018,

Acceptance 25-07-2018, Published 06-08-2018.

Corresponding Author:

Dr. McQueen Mendonca,

Department of Orthodontics,

A. B. Shetty Dental College,

Deralakatte,

Mangalore-575018,

Karnataka, India.

E-mail: mcqueenmendonca@yahoo.com

DOI: $10.14260 /$ jemds $/ 2018 / 802$

\section{BACKGROUND}

There is increasing demand for orthodontic treatment in society today. ${ }^{1}$ This can be due to increasing awareness of malocclusion, treatment availability, importance given to aesthetics and facial appearance. ${ }^{2}$ Orthodontic conditions are often considered to be of lesser importance by most health professionals, as they are not considered as life-threatening conditions. ${ }^{3}$ However, the early treatment of malocclusion is important, because it affects quality of life. ${ }^{4}$ Medical practitioners have an important role to play for patients with a vast majority of health-related complaints, as they are the primary caregivers. Involvement of medical practitioners in 
the process of screening, detection and referral of patients with oral health problems including malocclusion will be beneficial for the prevention and management of oral diseases and effective delivery of oral health care. ${ }^{5}$ Very few studies have been conducted to assess the medical students' awareness of orthodontics. There have been no known studies to have compared the responses of a medical college attached with a dental college with a stand-alone medical college. Hence, it was considered pertinent to conduct this study. The objective of this study was to assess as to whether there would be any differences in attitudes and awareness of orthodontics between medical students with an attached dental college $\{\mathrm{A}\}$ and students in a stand-alone medical college $\{B\}$.

\section{MATERIALS AND METHODS}

This comparative cross-sectional study was conducted in Mangalore among 132 first year MBBS students at a medical college with a dental college $\{A\}$ and 127 first year MBBS students in a standalone medical college $\{B\}$.

Sample size estimation was done based on the formula$\left(\mathrm{Z}_{\alpha}+\mathrm{Z}_{\beta}\right)^{2}\left(\mathrm{p}_{1} \mathrm{q}_{1}+\mathrm{p}_{2} \mathrm{q}_{2}\right)^{2} /\left(\mathrm{p}_{1)}-\mathrm{p}_{2}\right)^{2}$

Based on previous studies and results of my pilot study, considering $50 \%$ awareness among medical students attached with a dental college and expecting a minimum difference of awareness $15 \%$ among medical students without a dental college, about 90 students were needed in each group at $95 \%$ confidence interval and $80 \%$ power of study.

All first year medical students who were present on the day of the study were included in the survey to assess their awareness.

Permission was sought from the principal of $\{A\}$ medical college to conduct the survey at a time of convenience for the medical college students, preferably before or after their theory or a practical class, so as to cause minimum interference with their academics. Permission was granted to conduct the questionnaire survey after the anatomy practical class, so as to cause minimal disturbance to students.

A presentation was made before the Ethics Committee of $\{B\}$ medical college. A protocol was submitted to the Ethics Committee, which permitted the questionnaire survey study to be conducted subject to registration at the Clinical Trial Registry of India (CTRI). The CTRI trial acknowledgement number was REF/2015/11010154. Finally, permission was sought from the Dean of $\{\mathrm{B}\}$ medical college to conduct the survey just after the anatomy theory class.

A pre-piloted, validated, self-administered questionnaire used by Al Shahrani et $\mathrm{al}^{5}$ (Table 1) was distributed among the students. Prior permission from the concerned authorities and informed consent from the participants was taken. The students were informed of the objective of the survey and were given instructions on how the forms were to be filled. Implied coercion was done away with as none of the authors were involved in classroom teaching. It was ensured for completeness of the questionnaire while collecting it back. The response rate was $100 \%$. All forms were collected after 15 - 20 minutes.

Data collected was entered in Microsoft Excel. The statistical software package SPSS version 16.0 for Windows was employed for data analysis. Pearson's Chi-square test was used and a p-value of less than 0.05 was considered statistically significant.

\section{RESULTS}

A total of 259 first year MBBS students participated in the survey. Of them, 132 were from a medical college attached with a dental college $\{\mathrm{A}\}$ and 127 from a stand-alone medical college $\{B\}$.

Among the 132 students of $\{A\}, 55$ were males and 77 were females. Among the 127 students $\{B\}, 40$ were males and 87 were females.

Descriptive statistics, i.e. number and percentage was used to describe the variables (Table 2 and Table 3). Comparison of the knowledge of orthodontics is described in Table 4.

Only $26 \%$ of the participants in $\{B\}(n=34)$ had visited a dentist in the last 6 months as compared to $\{A\}$ where $40 \%$ of participants did visit a dentist $(n=53)$. This value was statistically significant (Graph 1).

$75 \%$ respondents in $\{B\}(n=95)$ were familiar with the term Orthodontics as compared to $\{A\} 80 \%(n=106)$.

Only $61 \% \quad(n=77)$ students in $\{B\}$ responded orthodontists correcting crooked teeth as compared to $74 \%$ $(n=98)$ in $\{A\}$. This value was statistically significant.

Close to $45 \%(n=57)$ of the students in $\{B\}$ felt mastication was most affected by malocclusion. This was followed by aesthetics $37 \%(n=47)$ and speech $18 \%(n=23)$. This is similar to the results from the study of $\{\mathrm{A}\}$ where the score for mastication was $48 \%(n=63)$, aesthetics was $44 \%$ $(n=58)$ and speech was $8 \%(n=11)$.

Treatment discomfort was a cause for concern for both groups, in $\{B\}$ and $\{A\}$. 51\% $(n=66)$ for $\{B\}$ and $44 \%(n=58)$ for $\{\mathrm{A}\}$.

More students in $\{B\} 45 \% \quad(n=57)$ would not refer Orthodontics as a career to their close relatives as compared to $\{\mathrm{A}\}$ respondents $30 \%(\mathrm{n}=40)$. This value was statistically significant (Graph 2).

There was a difference between male and female students' awareness and their attitudes towards orthodontics (Table 5). There were significant differences in the attitudes and awareness of the subject of Orthodontics between those students studying in a medical college with an attached dental college (A) when compared with those medical students studying in a stand-alone medical college (B). 


\section{Table 1}

Pre-piloted valid ated self-administered qu

Please tick the appropriate circle.

Age: years Gender: $\mathrm{M} \bigcirc \mathrm{F} \bigcirc$

1. Have you visited a dentist in the last 6 months? Yes $\bigcirc$

2. If yes, what was your reason for visiting the dentist? Pain $\bigcirc$

3. Are you familiar with the term Orthodontics? Yes $\bigcirc \quad \mathrm{N}$

4. Do you know which type of treatment is done in the orthodor Dentures $\bigcirc$ Fillings $\bigcirc$ correcting crooked teeth $\bigcirc$

5. Are you receiving orthodontic treatment at present or underv<smiles>O=[W]O</smiles>

6. Are any of your relatives receiving ortho dontic treatment pre: treatment previously?

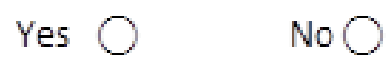

7. In your opinion, which daily function would be most affected I

Aesthetics $\bigcirc \quad$ Mastication $\bigcirc \quad$ Speech $\bigcirc$

8. Will you refer your close relatives to dentists in case you notic

$$
\text { Yes } \bigcirc \quad \text { No } \bigcirc
$$

9. Of the following, what would deter you from advising or persc treatment?

$$
\text { Cost } \bigcirc \quad \text { Time required } \bigcirc \quad \text { Treatment disc }
$$

10. Would you suggest orthodontics as a career to any of your cl

$$
\text { Yes } \bigcirc \quad \text { No } \bigcirc
$$

\begin{tabular}{|c|c|c|c|}
\hline Age in Years & Males & Females & Total \\
\hline 17 & 1 & 3 & 4 \\
\hline 18 & 28 & 54 & 82 \\
\hline 19 & 16 & 15 & 31 \\
\hline 20 & 8 & 5 & 13 \\
\hline 21 & 1 & 0 & 1 \\
\hline 22 & 1 & 0 & 1 \\
\hline Total & $\mathbf{5 5}$ & $\mathbf{7 7}$ & $\mathbf{1 3 2}$ \\
\hline \multicolumn{2}{r}{} \\
\hline
\end{tabular}


Medical College B (Without an Attached Dental College)

\begin{tabular}{|c|c|c|c|}
\hline Age in Years & Males & Females & Total \\
\hline 17 & 3 & 10 & 13 \\
\hline 18 & 24 & 58 & 82 \\
\hline 19 & 9 & 16 & 25 \\
\hline 20 & 4 & 3 & 7 \\
\hline Total & $\mathbf{4 0}$ & $\mathbf{8 7}$ & $\mathbf{1 2 7}$ \\
\hline
\end{tabular}

- $\quad$ Total males and females in both A and B medical colleges, 259.

- Total males in both A and B medical college, 95.

- Total females in both A and B medical college, 164.

\begin{tabular}{|c|c|c|c|c|c|c|c|c|c|}
\hline Question & & $\begin{array}{c}\text { Males } \\
\text { No (\%) (A) }\end{array}$ & $\begin{array}{c}\text { Males No } \\
\text { (\%) (B) }\end{array}$ & $\begin{array}{l}\text { Chi- } \\
\text { square } \\
\text { (A) }\end{array}$ & \begin{tabular}{|c|}
$P$ \\
value \\
(A) \\
\end{tabular} & $\begin{array}{c}\text { Females } \\
\text { No (\%) (A) }\end{array}$ & $\begin{array}{c}\text { Females No } \\
\text { (\%) (B) }\end{array}$ & $\begin{array}{c}\text { Total } \\
\text { No (\%) (A) }\end{array}$ & $\begin{array}{c}\text { Total } \\
\text { No (\%) (B) }\end{array}$ \\
\hline \multirow{2}{*}{$\begin{array}{l}\text { 1. Have you visited } \\
\text { a dentist in the } \\
\text { last } 6 \text { months? }\end{array}$} & Yes & $16(29.09)$ & $13(32.50)$ & 4.80 & $0.028^{*}$ & $37(48.05)$ & $21(24.13)$ & $53(40.15)$ & $34(26.77)$ \\
\hline & No & $39(70.91)$ & $27(67.50)$ & & & $40(51.94)$ & $66(75.86)$ & $79(59.84)$ & 93(73.22) \\
\hline \multirow{3}{*}{$\begin{array}{l}\text { 2. If yes, what was } \\
\text { your reason for } \\
\text { visiting the } \\
\text { dentist? }(n=53)\end{array}$} & Pain & $2(12.50)$ & $2(15.38)$ & 0.1 & 0.952 & $5(13.51)$ & $6(28.57)$ & $7(13.20)$ & $8(23.52)$ \\
\hline & $\begin{array}{l}\text { Routine } \\
\text { check-up }\end{array}$ & $9(56.25)$ & $10(76.92)$ & & & $22(59.45)$ & $5(23.80)$ & $31(58.49)$ & $15(44.11)$ \\
\hline & Others & $5(31.25)$ & $1((7.69)$ & & & $10(27.03)$ & $10(47.61)$ & $15(28.30)$ & 11(32.35) \\
\hline \multirow{2}{*}{$\begin{array}{l}\text { 3. Are you familiar } \\
\text { with the term } \\
\text { Orthodontics? }\end{array}$} & Yes & $41(74.54)$ & $25(62.50)$ & 1.98 & 0.160 & $65(84.41)$ & $70(80.45)$ & $106(80.30)$ & 95(74.80) \\
\hline & No & $14(25.46)$ & $15(37.50)$ & & & $12(15.58)$ & $17(19.54)$ & $26(19.69)$ & $32(25.19)$ \\
\hline \multirow{3}{*}{$\begin{array}{l}\text { 4. Do you know } \\
\text { which type of } \\
\text { treatment is done } \\
\text { in the orthodontic } \\
\text { specialty? }\end{array}$} & Dentures & $5(9.09)$ & $4(10.00)$ & 0.808 & 0.668 & $10(12.98)$ & $16(18.39)$ & $15(11.36)$ & $20(15.74)$ \\
\hline & Fillings & $7(12.72)$ & $13(32.50)$ & & & $12(15.58)$ & $17(19.54)$ & $19(14.39)$ & $30(23.62)$ \\
\hline & $\begin{array}{l}\text { Correcting } \\
\text { crooked } \\
\text { teeth }\end{array}$ & 43 (78.18) & $23(57.50)$ & & & $55(71.43)$ & $54(62.06)$ & $98(74.24)$ & $77(60.62)$ \\
\hline \multirow[b]{2}{*}{$\begin{array}{l}\text { 5. Are you } \\
\text { receiving } \\
\text { orthodontic } \\
\text { treatment at } \\
\text { present or } \\
\text { underwent } \\
\text { orthodontic } \\
\text { treatment } \\
\text { previously? }\end{array}$} & Yes & $14(25.45)$ & $12(30.00)$ & 3.13 & \begin{tabular}{|l|}
0.077 \\
\end{tabular} & $31(40.26)$ & $26(29.88)$ & $45(34.09)$ & $38(29.92)$ \\
\hline & No & $41(74.54)$ & $28(70.00)$ & & & $46(59.74)$ & $61(70.11)$ & $87(65.90)$ & $89(70.07)$ \\
\hline \multirow[b]{2}{*}{$\begin{array}{l}\text { 6. Are any of your } \\
\text { relatives receiving } \\
\text { orthodontic } \\
\text { treatment } \\
\text { presently or have } \\
\text { undergone } \\
\text { orthodontic } \\
\text { treatment } \\
\text { previously? }\end{array}$} & Yes & 32 (58.18) & $19(47.50)$ & 0.891 & 0.345 & $51(66.23)$ & $38(43.67)$ & $83(62.87)$ & $57(44.88)$ \\
\hline & No & 23 (41.81) & $21(52.50)$ & & & $26(33.76)$ & $49(56.32)$ & $49(37.12)$ & $70(55.11)$ \\
\hline \multirow{3}{*}{$\begin{array}{l}\text { 7. In your opinion, } \\
\text { which daily } \\
\text { function would be } \\
\text { most affected by } \\
\text { maligned and } \\
\text { crooked teeth? }\end{array}$} & Aesthetics & $19(34.54)$ & $12(30.00)$ & 6.46 & $0.040^{*}$ & $39(50.64)$ & $35(40.22)$ & $58(43.94)$ & $47(37.00)$ \\
\hline & Mastication & $28(50.9)$ & $17(42.50)$ & & & $35(45.45)$ & $40(45.97)$ & $63(47.72)$ & $57(44.88)$ \\
\hline & Speech & $8(14.55)$ & $11(27.50)$ & & & $3(3.9)$ & $12(13.79)$ & $11(8.33)$ & 23(18.11) \\
\hline \multirow{2}{*}{$\begin{array}{l}\text { 8. Will you refer } \\
\text { your close } \\
\text { relatives to } \\
\text { dentists in case } \\
\text { you notice } \\
\text { maligned teeth? }\end{array}$} & Yes & $53(96.36)$ & $34(85.00)$ & 0.522 & 0.470 & $72(93.5)$ & $74(85.05)$ & 125(94.69) & $108(85.03)$ \\
\hline & No & $2(3.63)$ & $6(15.00)$ & & & $5(6.49)$ & $13(14.94)$ & $7(5.30)$ & $19(14.96)$ \\
\hline \multirow{3}{*}{$\begin{array}{l}\text { 9. Of the following, } \\
\text { what would deter } \\
\text { you from advising } \\
\text { or personally } \\
\text { undergoing } \\
\text { orthodontic } \\
\text { treatment? }\end{array}$} & Cost & $19(34.54)$ & $7(17.50$ & 0.02 & 0.990 & $27(35.06)$ & $28(32.18)$ & $46(34.84)$ & $35(27.55)$ \\
\hline & $\begin{array}{c}\text { Time } \\
\text { required }\end{array}$ & $12(21.81)$ & $10(25.00)$ & & & $16(20.78)$ & 16(18.39) & $28(21.21)$ & $26(20.47)$ \\
\hline & $\begin{array}{l}\text { Treatment } \\
\text { discomfort }\end{array}$ & $24(43.63)$ & $23(57.50)$ & & & $34(44.15)$ & $43(49.42)$ & $58(43.94)$ & $66(51.96)$ \\
\hline
\end{tabular}




\begin{tabular}{|l|c|c|c|c|c|c|c|c|c|}
\hline $\begin{array}{l}10 . \text { Would you } \\
\text { suggest } \\
\text { orthodontics as a } \\
\begin{array}{l}\text { career to any of } \\
\text { your close } \\
\text { relatives? }\end{array}\end{array}$ & Yes & $37(67.27)$ & $15(37.50)$ & 0.262 & 0.609 & $55(71.43)$ & $55(63.21)$ & $92(69.69)$ & $70(55.11)$ \\
\hline \multicolumn{7}{|c|}{ Table 3. Descriptive Statistics of the variables in the Study } \\
\hline
\end{tabular}

${ }^{*} \mathrm{p}<0.05$, significant

\begin{tabular}{|c|c|c|c|c|c|}
\hline Question & & College A & College B & Chi & $\mathbf{P}$ \\
\hline \multirow{2}{*}{$\begin{array}{l}\text { 1. Have you visited a dentist in the last } 6 \\
\text { months? }\end{array}$} & Yes & 53 & 34 & 5.194 & $0.02 *$ \\
\hline & No & 79 & 93 & & \\
\hline \multirow{3}{*}{$\begin{array}{l}\text { 2. If yes, what was your reason for visiting } \\
\text { the dentist? }\end{array}$} & Pain & 7 & 8 & 2.2029 & 0.332 \\
\hline & Routine check-up & 31 & 15 & & \\
\hline & Others & 15 & 11 & & \\
\hline \multirow{2}{*}{$\begin{array}{l}\text { 3. Are you familiar with the term } \\
\text { Orthodontics? }\end{array}$} & Yes & 106 & 95 & 1.127 & 0.2885 \\
\hline & No & 26 & 32 & & \\
\hline \multirow{3}{*}{$\begin{array}{l}\text { 4. Do you know which type of treatment } \\
\text { is done in the orthodontic specialty? }\end{array}$} & Dentures & 15 & 20 & 5.6092 & $0.06^{*}$ \\
\hline & Fillings & 19 & 30 & & \\
\hline & $\begin{array}{c}\text { Correcting } \\
\text { crooked teeth }\end{array}$ & 98 & 77 & & \\
\hline \multirow{2}{*}{$\begin{array}{l}\text { 5. Are you receiving orthodontic } \\
\text { treatment at present or underwent } \\
\text { orthodontic treatment previously? }\end{array}$} & Yes & 45 & 38 & 0.517 & 0.4722 \\
\hline & No & 87 & 89 & & \\
\hline \multirow{2}{*}{$\begin{array}{l}\text { 6. Are any of your relatives receiving } \\
\text { orthodontic treatment presently or have } \\
\text { undergone orthodontic treatment } \\
\text { previously? }\end{array}$} & Yes & 83 & 57 & 8.441 & $0.0037^{*}$ \\
\hline & No & 49 & 70 & & \\
\hline \multirow{3}{*}{$\begin{array}{l}\text { 7. In your opinion, which daily function } \\
\text { would be most affected by maligned and } \\
\text { crooked teeth? }\end{array}$} & Aesthetics & 58 & 47 & 5.59 & $0.06^{*}$ \\
\hline & Mastication & 63 & 57 & & \\
\hline & Speech & 11 & 23 & & \\
\hline \multirow{2}{*}{$\begin{array}{l}\text { 8. Will you refer your close relatives to } \\
\text { dentists in case you notice maligned } \\
\text { teeth? }\end{array}$} & Yes & 125 & 108 & 6.685 & $0.0097^{*}$ \\
\hline & No & 7 & 19 & & \\
\hline \multirow{3}{*}{$\begin{array}{l}\text { 9. Of the following, what would deter you } \\
\text { from advising or personally undergoing } \\
\text { orthodontic treatment? }\end{array}$} & Cost & 46 & 35 & 1.98 & 0.37 \\
\hline & Time required & 28 & 26 & & \\
\hline & $\begin{array}{l}\text { Treatment } \\
\text { discomfort }\end{array}$ & 58 & 66 & & \\
\hline \multirow{2}{*}{$\begin{array}{l}\text { 10. Would you suggest orthodontics as a } \\
\text { career to any of your close relatives? }\end{array}$} & Yes & 92 & 70 & 5.873 & $0.0154 *$ \\
\hline & No & 40 & 57 & & \\
\hline
\end{tabular}

Table 4. Comparison of Knowledge of Orthodontics among 2 of the Colleges ${ }^{*} \mathrm{p}<0.05$, significant.

\begin{tabular}{|c|c|c|c|c|c|c|c|c|c|}
\hline Question & & Males A & Males B & chi square & p & Females A & Females B & chi square & p \\
\hline \multirow{2}{*}{$\begin{array}{l}\text { 1. Have you visited } \\
\text { a dentist in the last } \\
6 \text { months? }\end{array}$} & Yes & 16 & 13 & 0.127 & 0.72 & 37 & 21 & 10.219 & $0.0014^{*}$ \\
\hline & No & 39 & 27 & & & 40 & 66 & & \\
\hline \multirow{3}{*}{$\begin{array}{l}\text { 2. If yes, what was } \\
\text { your reason for } \\
\text { visiting the dentist? }\end{array}$} & Pain & 2 & 2 & 2.435 & 0.295 & 5 & 6 & 6.9 & $0.03^{*}$ \\
\hline & $\begin{array}{l}\text { Routine } \\
\text { check up }\end{array}$ & 9 & 10 & & & 22 & 5 & & \\
\hline & Others & 5 & 1 & & & 10 & 10 & & \\
\hline \multirow{2}{*}{$\begin{array}{l}\text { 3. Are you familiar } \\
\text { with the term } \\
\text { Orthodontics? }\end{array}$} & Yes & 41 & 25 & 1.584 & 0.2081 & 65 & 70 & 0.439 & 0.5075 \\
\hline & No & 14 & 15 & & & 12 & 17 & & \\
\hline \multirow{3}{*}{$\begin{array}{l}\text { 4. Do you know } \\
\text { which type of } \\
\text { treatment is done } \\
\text { in the orthodontic } \\
\text { specialty? }\end{array}$} & Dentures & 5 & 4 & 5.74 & 0.056 & 10 & 16 & 1.65 & 0.437 \\
\hline & Fillings & 7 & 13 & & & 12 & 17 & & \\
\hline & $\begin{array}{l}\text { Correcting } \\
\text { crooked } \\
\text { teeth }\end{array}$ & 43 & 23 & & & 55 & 54 & & \\
\hline \multirow[b]{2}{*}{$\begin{array}{l}\text { 5. Are you } \\
\text { receiving } \\
\text { orthodontic } \\
\text { treatment at } \\
\text { present or } \\
\text { underwent } \\
\text { orthodontic } \\
\text { treatment }\end{array}$} & Yes & 14 & 12 & 0.241 & 0.6237 & 31 & 26 & 1.939 & 0.1638 \\
\hline & No & 41 & 28 & & & 46 & 61 & & \\
\hline
\end{tabular}




\begin{tabular}{|c|c|c|c|c|c|c|c|c|c|}
\hline \multirow{3}{*}{$\begin{array}{l}\text { previously? } \\
\text { 6. Are any of your } \\
\text { relatives receiving } \\
\text { orthodontic } \\
\text { treatment } \\
\text { presently or have } \\
\text { undergone } \\
\text { orthodontic } \\
\text { treatment } \\
\text { previously? }\end{array}$} & & & & & & & & & \\
\hline & Yes & 32 & 19 & 1.063 & 0.3026 & 51 & 38 & 8.374 & $0.0038^{*}$ \\
\hline & No & 23 & 21 & & & 26 & 49 & & \\
\hline \multirow{3}{*}{$\begin{array}{l}\text { 7. In your opinion, } \\
\text { which daily } \\
\text { function would be } \\
\text { most affected by } \\
\text { maligned and } \\
\text { crooked teeth? }\end{array}$} & Aesthetics & 19 & 12 & 2.43 & 0.295 & 39 & 35 & 5.359 & 0.068 \\
\hline & mastication & 28 & 17 & & & 35 & 40 & & \\
\hline & Speech & 8 & 11 & & & 3 & 12 & & \\
\hline \multirow{2}{*}{$\begin{array}{l}\text { 8. Will you refer } \\
\text { your close relatives } \\
\text { to dentists in case } \\
\text { you notice } \\
\text { maligned teeth? }\end{array}$} & Yes & 53 & 34 & 3.878 & $0.04^{*}$ & 72 & 74 & 2.984 & 0.0841 \\
\hline & No & 2 & 6 & & & 5 & 13 & & \\
\hline \multirow{3}{*}{$\begin{array}{l}\text { 9. Of the following, } \\
\text { what would deter } \\
\text { you from advising } \\
\text { or personally } \\
\text { undergoing } \\
\text { orthodontic } \\
\text { treatment? }\end{array}$} & Cost & 19 & 7 & 3.459 & 0.177 & 27 & 28 & 0.4621 & 0.79 \\
\hline & $\begin{array}{c}\text { time } \\
\text { required }\end{array}$ & 12 & 10 & & & 16 & 16 & & \\
\hline & $\begin{array}{l}\text { treatment } \\
\text { discomfort }\end{array}$ & 24 & 23 & & & 34 & 43 & & \\
\hline \multirow{2}{*}{$\begin{array}{l}\text { 10. Would you } \\
\text { suggest } \\
\text { orthodontics as a } \\
\text { career to any of } \\
\text { your close } \\
\text { relatives? }\end{array}$} & Yes & 37 & 15 & 8.285 & $0.004^{*}$ & 55 & 55 & 1.247 & 0.2642 \\
\hline & No & 18 & 25 & & & 22 & 32 & & \\
\hline
\end{tabular}

$* \mathrm{p}<0.05$, significant.

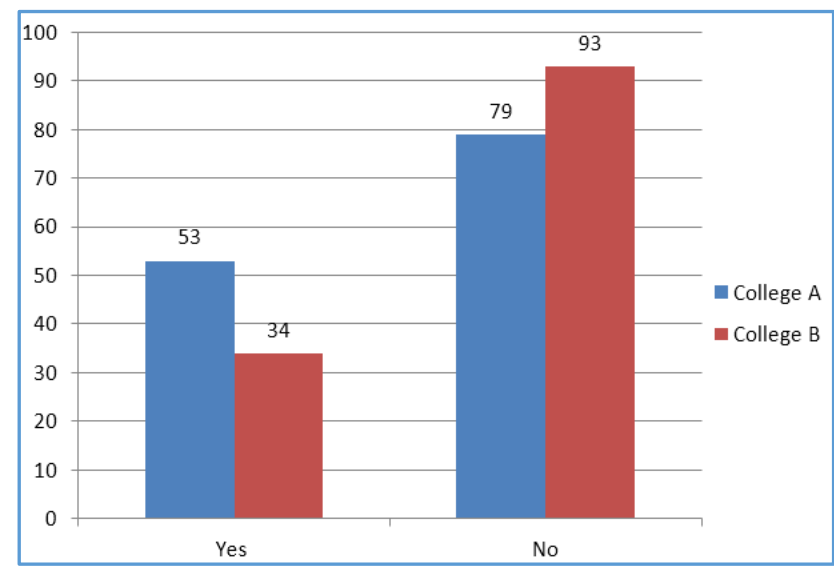

Graph 1. Students visiting a Dentist

\section{DISCUSSION}

The general purpose of the present study was to assess the differences in the attitudes and awareness of Orthodontics between first year MBBS medical college students studying in a medical college with an attached dental college and those students studying in a stand-alone medical college. A validated questionnaire was used. Medical College students' exposure to the subject of dentistry is very minimal, let alone the field of Orthodontics. As tomorrow's medical practitioners they would probably encounter patients with

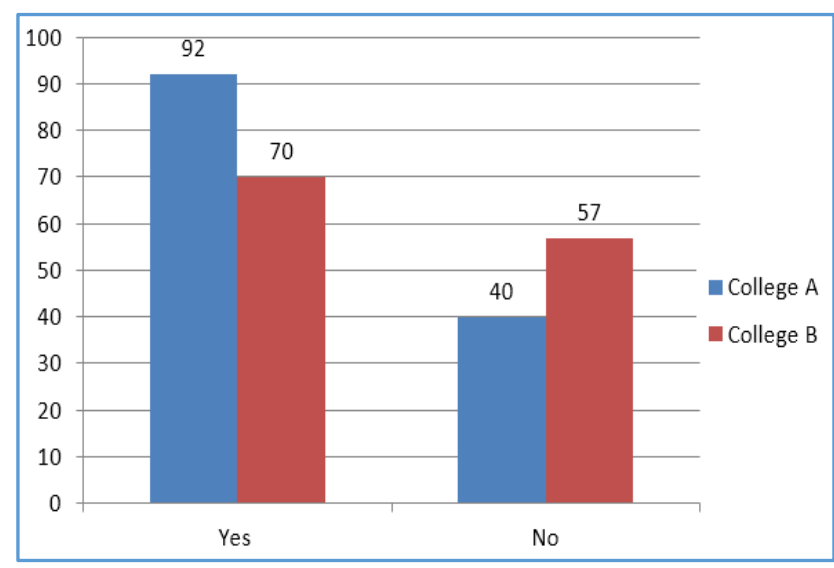

Graph 2. Would you suggest Orthodontics as a Career

various malocclusions or dentofacial defects, who would not have an aesthetically pleasing profile. Hence, this study was conducted to assess the students.

Very few studies have been conducted to assess the medical students' awareness of orthodontics. There have been no known studies to have compared the responses of a medical college attached with a dental college with a standalone medical college.

In a study ${ }^{6}$ conducted in 2016 to assess the knowledge and attitudes towards orthodontics among paediatricians in 
Haryana, it was observed that there was a low level of awareness regarding orthodontics among paediatricians. The study concluded by saying that there was a necessity for education of paediatricians regarding orthodontics. This corroborates with the findings of our study

In our study we found more medical students in $\{A\}$ visiting a dentist as compared to $\{B\}$. This could be due to the fact that the medical students in $\{\mathrm{A})$ have better access to dental treatment as compared to those in $\{\mathrm{B}\}$.

A statistically significant number of medical students in $\{A\}$ responded correctly that orthodontists were involved in correcting crooked teeth than those medical students in $\{B\}$. This could be due to more exposure of students in $\{A\}$ to a dental college.

When it came to deterrence from advising or personally undergoing orthodontic treatment, the treatment discomfort scored over the cost or the time required for orthodontic treatment. This finding suggests that orthodontists can advise patients about the various appliances available for orthodontic treatment. Communication between the orthodontist and the patient regarding diagnosis and treatment planning is very important, as has been noted in an article $^{7}$ which states that patients and parents are often amused to know that there is more than one proper treatment plan for any case. Another article ${ }^{8}$ suggests the importance of good communication between the orthodontist and the patient.

It was observed in our study that a statistically significant number of students in $\{\mathrm{B}\}$ would not refer Orthodontics as a career to their close relatives as compared to respondents in $\{A\}$. The study 5 done in 2014 has mentioned the need for creating more orthodontic awareness among medical students. This is in concurrence with our study.

The findings of a study ${ }^{9}$ conducted to observe professional opinions on the advantages of orthodontic treatment also states that both general dentists and orthodontists rated the psychosocial gain from orthodontic treatment higher than the dental gain. They also felt that orthodontic treatment reduces the chances of dental disease. The data from our study also suggests that aesthetics may be a motivation for seeking treatment, especially for female patients.

There was a difference between male and female students' awareness and their attitudes towards orthodontics. There was a difference among male and female students' responses regarding which daily function would be most affected by malocclusion. $45.12 \%$ of the total number of females $(n=164)$ felt aesthetics as being most affected as compared to $32.63 \%$ in males $(n=95)$. This data suggests that the female participants consider aesthetics to be more affected than mastication or speech. These findings are similar to similar studies conducted in Nigeria $^{3}$ and Saudi Arabia. ${ }^{5}$

$67.07 \%$ of the females $(n=164)$ would suggest orthodontics as a career as compared to $54.73 \%$ males ( $\mathrm{n}=95)$.

It has been mentioned in various studies ${ }^{10,11,12}$ that patients who have completed orthodontic treatment may benefit in their dental compliance and oral health indirectly by psychological factors. ${ }^{10}$ Also they have an improved oral health-related quality of life than did the untreated patients who were waiting for treatment. ${ }^{11}$ The findings of our study suggest that it would benefit society at large if there was better awareness of Orthodontics among medical college students.

General dental practitioners are often the first dental professionals to suggest orthodontic treatment and to refer patients to orthodontic specialists. With the growing emphasis on cosmetic dentistry, more adults are likely to seek information regarding orthodontic surgery. ${ }^{13}$

The limitation of this present study was a limited sample size. There is a scope for further studies of similar nature to be conducted on a larger scale in future. In spite of the limitations of the present study, the findings are useful for the orthodontic profession and also the fact that this study facilitates for a debate in the medical community as to the amount of awareness the medical students must have about the sub-specialties of dentistry.

The findings of a study ${ }^{14}$ conducted in 2009 to assess the current evidence of the relationship between malocclusion/orthodontic treatment need and quality of life, mentions that there is a need for further studies so that outcomes are uniform and thus amenable to meta-analysis. Hence, better coordination between the medical and dental fraternity would lead to more awareness and better treatment outcomes.

\section{CONCLUSION}

Medical students who studied in an institution with an attached dental college had better awareness of the subject of orthodontics as compared to medical students of a standalone medical college.

Medical students who studied in a medical college without an attached dental college had average awareness of orthodontics as a sub-specialty of dentistry. A basic introduction to dental sub-specialties would help them identify dentofacial problems and make appropriate referrals.

Orthodontists can improve their communication skills and allay patient's fears about treatment discomfort. Close contact with the orthodontist is a way to make patients aware of the importance of maintaining oral health.

\section{ACKNOWLEDGEMENTS}

Special thanks to Dr. Ibrahim Al Shahrani, Dean, King Khalid University, Saudi Arabia, for his permission to use the questionnaire.

The author would like to thank the A. B. Shetty Dental College Principal and Dean, Prof. Dr. U. S. Krishna Nayak; K. S. Hegde Medical College Dean, Dr. Satish Kumar Bhandary, the Head of Department of ENT; Dr. Martin Lucas, K. S. Hegde Medical College, the Head of Department of Anatomy; and all the first year MBBS students of K. S. Hegde Medical Academy, Nitte University, Mangalore for their participation in the study.

The author would like to thank the Fr. Muller Medical College administrator Rev. Fr. Rudolph Ravi D'Sa, the Dean Dr. J. P. Alva, the Chief of Medical Services Dr. Sanjeev Rai and the secretarial staff of Fr. Muller Medical College, Mangalore for their help. Thanks to Dr. Prakash Shetty, Head, Department of Anatomy, Fr. Muller Medical College, and to the 1st MBBS students for their participation in the study. 


\section{REFERENCES}

[1] Thilander B, Pena L, Infante C, et al. Prevalence of malocclusion and orthodontic treatment need in children and adolescents in Bogota, Colombia. An epidemiological study related to different stages of dental development. Eur J Orthod 2001;23(2):153-67.

[2] Tufekci E, Jahangiri A, Lindauer SJ. Perception of profile among laypeople, dental students and orthodontic patients. Angle Orthod 2008;78(6):983-7.

[3] Adegbite KO, Ogunbanjo B, Ajisafe O, et al. Knowledge of orthodontics as a dental specialty: a preliminary survey among LASUCOM students. Ann Med Health Sci Res 2012;2(1):14-8.

[4] Kenealy P, Hackett P, Frude N, et al. The psychological benefit of orthodontic treatment. Its relevance to dental health education. N Y State Dent J 1991;57(5):32-4.

[5] Shahrani I, Kandyala R Medical students' awareness of orthodontics: a cross sectional study in King Khalid University, Abha, Saudi Arabia. Arch Orofac Sci 2014;9(1):17-24.

[6] Sharma R, Kumar S, Singla A, et al. Knowledge, attitude and practices of pediatricians regarding malocclusion in Haryana, India. J Indian Assoc Public Health Dent 2016;14(2):197-201.

[7] Ackerman JL, Proffit WR. Communication in orthodontic treatment planning: bioethical and informed consent issues. Angle Orthod 1995;65 (4):253-61.
[8] Twigge E, Roberts RM, Jamieson L, et al. The psychosocial impact of malocclusions and treatment expectations of adolescent orthodontic patients. Eur J Orthod 2015;38(6):593-601.

[9] Hunt O, Hepper P, Johnston C, et al. Professional perceptions of the benefits of orthodontic treatment. European Journal of Orthodontics 2001;23(2):315-23.

[10] Klages U, Rost F, Wehrbein H, et al. Perception of occlusion, psychological impact of dental esthetics, history of orthodontic treatment and their relation to oral health in naval recruits. Angle Orthod 2007;77(4):675-80.

[11] Palomares NB, Celeste RK, Oliveira BH, et al. How does orthodontic treatment affect young adults' oral healthrelated quality of life? Am J Orthod Dentofacial Orthop 2012;141(6):751-58.

[12] Lin F, Ren M, Yao L, et al. Psychosocial impact of dental esthetics regulates motivation to seek orthodontic treatment. Am J Orthod Dentofacial Orthop 2016;150(3):476-82.

[13] Buttke TM, Proffit WR. Referring adult patients for orthodontic treatment. J Am Dent Assoc 1999;130(1):73-9.

[14] Liu Z, McGrath C, Hägg U. The impact of malocclusion/orthodontic treatment need on the quality of life. A systematic review. Angle Orthod 2009;79(3):585-91. 